\title{
Effect of feed pellet size and tank water level on growth performance in juvenile pikeperch, Sander lucioperca (L.), reared in a recirculating system
}

\author{
Michał Kozłowski, Iwona Piotrowska, Bożena Szczepkowska
}

Received - 13 January 2021/Accepted - 23 June 2021. Published online: 30 June 2021; @Inland Fisheries Institute in Olsztyn, Poland Citation: Kozłowski, M., Piotrowska, I., Szczepkowska, B. (2021). Effect of feed pellet size and tank water level on growth performance in juvenile pikeperch, Sander lucioperca (L.), reared in a recirculating system. Fisheries Aquatic \& Life 29, 88-99

\begin{abstract}
Three 28-day experiments were performed to assess the impact of two sinking feed pellet sizes $(0.5-1.0$ and 0.9-1.6 mm for experiment I, 0.9-1.6 and 1.3-2.0 mm for experiment II, and 1.3-2.0 and 1.6-2.4 mm for experiment III) and two tank water levels $(0.50$ and $0.65 \mathrm{~m})$ on the growth performance of juvenile pikeperch of different mean initial body weights in experiment I, II, III respectively $(1.1 \pm 0.1 \mathrm{~g}$, $5.1 \pm 0.2 \mathrm{~g}, 16.6 \pm 0.5 \mathrm{~g})$ at different ages $(67,102$, and 137 days post hatch). Two-factor analysis of variance showed that the growth of pikeperch was positively correlated with feed pellet size in experiment I, both feed pellet size and water level in experiment II, and water level in experiment III. The feed pellet sizes of 0.9-1.6 and 1.3-2.0 mm at body weights of 1.1 $\mathrm{g}$ and $5.1 \mathrm{~g}$, respectively, are recommended to promote more efficient pikeperch growth rates. In the case of pikeperch with a body weight of $16.6 \mathrm{~g}$, the feed pellet size was less important than the tank water level.
\end{abstract}

Keywords: food particle size, tank water depth, growth rate, percid culture, fish farming practices

\section{Introduction}

\footnotetext{
M. Kozłowski [ $\left.\Xi^{\circ}\right]$, I. Piotrowska, B. Szczepkowska

Department of Sturgeon Fish Breeding, Stanislaw Sakowicz Inland Fisheries Institute, Olsztyn, Poland, 11-610 Pozezdrze, Pieczarki 50

E-mail: m.kozlowski@infish.com.pl
}

Among many species of freshwater fishes, pikeperch (Sander lucioperca (L.)) has been identified as a promising new species in intensive fish farming (Dalsgaard et al. 2013, Kestemont et al. 2015). The current production of this species in aquaculture is mainly directed toward niche markets (Toner 2015) and increasing production is limited (Overton et al. 2015, Policar et al. 2019). The technology of pikeperch production is still limited because of high mortality occurring at larval and juvenile stages (Kestemont et al. 2003, Molnár et al. 2004, Colchen et al. 2019). This could be related to unsuitable rearing and feeding conditions causing high stress levels. Scientific investigation focuses primarily on improving the zootechnical performance of fishes. However, there is a significant gap between the knowledge provided by research and the implementation of such knowledge in commercial practice (Policar et al. 2019). Additionally, obtaining higher production rates with pikeperch, which is a high-quality, healthy product, can contribute significantly to the development of the freshwater aquaculture market (Overton et al. 2015, Policar et al. 2019).

In aquaculture studies, little attention has been paid to tank water level, which is a crucial factor affecting the growth, survival, yield, and welfare of fishes. While there are several studies on the impact of 
water levels on the survival, growth, and behavior of different fish species in recirculating aquaculture systems (RAS) (Einarsdóttir and Nilssen 1996, Flodmark et al. 2004, Kozłowski et al. 2009), more attention has been focused on water depths in ponds (El Naggar et al. 2006, Ali et al. 2013, Hosen et al. 2019, Abdel-Hay et al. 2020) and the impact of water level fluctuations on the species communities in rivers, lakes, and reservoirs (Kahi et al. 2008, Bucat et al. 2012). In pikeperch tank water levels might affect its growth, because this species takes feed mainly from the water column (Zakęś 2009, Kozłowski et al. 2014).

Fish growth rates are related closely to feed pellet size and composition, but feed of larger sizes is not necessarily more beneficial for fishes (Wanzenböck 1995). When large fishes consume small food pellets, this can lead to insufficient net energy (Pandian and Vivekanandan 1985, Dos Santos et al. 1993). Therefore, feed pellets of moderate size can result in higher net energy consumption, and promote better growth. Similar conclusions were reported in many studies on different species, such as Atlantic salmon (Salmo salar (L.)) (Wańkowski and Thorpe 1979), common carp (Cyprinus carpio (L.) (Hasan and Macintosh 1992, Wang et al. 1994), African catfish (Clarias gariepinus Burchell) (Hossain et al. 2000), and gilthead bream (Sparus aurata (L.)) (Goldan et al. 1997). It was also documented that larger than optimal feed pellet size increased the body growth rates of Arctic charr (Salvelinus alpinus (L.)) (Tabachek 1988) and Nile tilapia (Oreochromis niloticus (L.)) (Azaza et al. 2010). In pikeperch, data regarding the effect of feed pellet size on growth are only available for fish of body weights exceeding 100 g (Zakęś et al. 2013, Mattila and Koskela 2017), and the results of these studies showed that pikeperch with body weights of 74-102 g grew better because of the smaller feed pellet size, while in a group of larger fish (125-170 g) no effect of feed pellet size on pikeperch growth was observed. In pikeperch with body weights of about $220 \mathrm{~g}$, decreased growth was recorded when the fish were fed pellets size larger than $9.8-10.3 \mathrm{~mm}$. According to Zakęś et al. (2013) and Mattila and Koskela (2017), the larger feed pellet size increased the coefficient of body weight variation, which was very unfavorable for production. Therefore, the appropriate feed pellet size for pikeperch can affect its growth, but little is known about the appropriate feed pellet size for smaller pikeperch.

The aim of this study was to determine the effect of using different feed pellet sizes and two water levels on the rearing parameters of juvenile pikeperch in RAS depending on initial body weight.

\section{Materials and methods}

\section{Origin of larvae, experimental design, and rearing conditions}

The research complied with Polish animal welfare regulations and was approved by the Local Ethics Committee for Animal Experimentation of the Inland Fisheries Institute in Olsztyn, Poland. The juvenile pikeperch were obtained through artificial reproduction (Department of Sturgeon Fish Breeding in Pieczarki, Inland Fisheries Institute in Olsztyn, Poland). The fish were caught immediately before the planned date of reproduction from a pond. Twelve females (individual body weight $1.5-2.6 \mathrm{~kg}$ ) and six males (individual body weight $1.5-2.4 \mathrm{~kg}$ ) were moved to the hatchery. The spawners were stimulated hormonally with human chorionic gonadotrophin (hCG) at a dose of $400 \mathrm{IU} \mathrm{hCG} \mathrm{kg}{ }^{-1}$ body weight (BW)

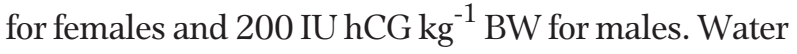
temperature during spawning was $16^{\circ} \mathrm{C}$. The eggs were fertilized on an artificial substrate in a tank three days after hormonal stimulation. The hatched larvae were harvested after five days and placed in a different RAS. The fish were trained to consume commercial feed according to established procedures (Kestemont et al. 2007, Zakęś 2009). The research was conducted in a RAS equipped with an oxygenation system. The biofilter was filled with plastic medium (Bioelements Light, RK Plast A/S, Denmark).

Three experiments (I, II, III) were conducted using fish of different initial body weights $(1.1 \mathrm{~g}, 5.1 \mathrm{~g}$, $16.6 \mathrm{~g})$. A $2 \times 2$ factorial treatment design was used to 
Table 1

Experimental conditions and design

\begin{tabular}{|c|c|c|c|c|c|c|c|c|c|}
\hline $\begin{array}{l}\text { Experi- } \\
\text { ment }\end{array}$ & Group & $\begin{array}{l}\text { Water level } \\
\text { (m) }\end{array}$ & $\begin{array}{l}\text { Feed pel- } \\
\text { let size } \\
(\mathrm{mm})\end{array}$ & $\begin{array}{l}\text { Fish number } \\
\text { per tank* }\end{array}$ & $\begin{array}{l}\text { Stocking } \\
\text { density (kg } \\
\left.\mathrm{m}^{-3}\right)\end{array}$ & $\begin{array}{l}\text { Initial body } \\
\text { weight }(\mathrm{g})^{*}\end{array}$ & $\begin{array}{l}\text { Age } \\
(\mathrm{DPH})^{*}\end{array}$ & $\begin{array}{l}\text { Feeding } \\
\text { Rate }(\% \\
\left.\text { BW day }{ }^{-1}\right)^{*}\end{array}$ & $\begin{array}{l}\text { Water tem- } \\
\text { perature } \\
\left({ }^{\circ} \mathrm{C}\right)^{*}\end{array}$ \\
\hline \multirow[t]{4}{*}{ I } & $\mathrm{L}_{\mathrm{I}} \mathrm{F} 1$ & 0.50 & $0.5-1.0$ & & 0.47 & & & & \\
\hline & $\mathrm{H}_{\mathrm{I}}-\mathrm{F} 1$ & 0.65 & $0.9-1.6$ & 400 & 0.61 & $1.1 \pm 0.1$ & 67 & 4.0 & $20.8 \pm 0.5$ \\
\hline & $\mathrm{L}_{\mathrm{I}}-\mathrm{F} 2$ & 0.50 & $0.5-1.0$ & & 0.47 & & & & \\
\hline & $\mathrm{H}_{\mathrm{I}^{-}} \mathrm{F} 2$ & 0.65 & $0.9-1.6$ & & 0.61 & & & & \\
\hline \multirow[t]{4}{*}{ II } & $\mathrm{L}_{\mathrm{II}}-\mathrm{F} 2$ & 0.50 & $0.9-1.6$ & & 1.63 & & & & \\
\hline & $\mathrm{H}_{\mathrm{II}}-\mathrm{F} 2$ & 0.65 & $1.3-2.0$ & 300 & 2.13 & $5.1 \pm 0.2$ & 102 & 3.0 & $22.6 \pm 0.4$ \\
\hline & $\mathrm{L}_{\mathrm{II}}-\mathrm{F} 3$ & 0.50 & $0.9-1.6$ & & 1.63 & & & & \\
\hline & $\mathrm{H}_{\mathrm{II}}-\mathrm{F} 3$ & 0.65 & $1.3-2.0$ & & 2.13 & & & & \\
\hline \multirow[t]{4}{*}{ III } & $\mathrm{L}_{\text {III-F3 }}$ & 0.50 & $1.3-2.0$ & & 3.55 & & & & \\
\hline & $\mathrm{H}_{\text {III }}-\mathrm{F} 3$ & 0.65 & $1.6-2.4$ & 200 & 4.61 & $16.6 \pm 0.5$ & 137 & 2.0 & $21.7 \pm 0.7$ \\
\hline & $\mathrm{L}_{\mathrm{III}}-\mathrm{F} 4$ & 0.50 & $1.3-2.0$ & & 3.55 & & & & \\
\hline & $\mathrm{H}_{\text {III }}-\mathrm{F} 4$ & 0.65 & $1.6-2.4$ & & 4.61 & & & & \\
\hline
\end{tabular}

Abbreviations: BW - body weight, DPH - day post-hatch

* Initial body weight, age, feeding rate and water temperature were the same in each treatment of the individual experiments

evaluate the effect of water tank level $(0.50$ and 0.65 m) and feed pellet size (F1, F2, F3, F4) on pikeperch growth performance (Table 1). The fish were sorted before each experiment. In experiment I, at 67 days post hatch (DPH) the pikeperch had a mean body weight $\left(\mathrm{BW}_{\mathrm{i}}\right)$ of $1.1 \pm 0.1 \mathrm{~g}$ and a body length of $4.6 \pm$ $0.4 \mathrm{~cm}$. Stocking density was 400 individuals per tank. Two water levels $\left(0.50 \mathrm{~m}\right.$ - group $\mathrm{L}_{\mathrm{I}}$ and $0.65 \mathrm{~m}$ - group $\mathrm{H}_{\mathrm{I}}$ ) were used in the tanks. The stocking density in group $\mathrm{L}_{\mathrm{I}}$ was $0.47 \mathrm{~kg} \mathrm{~m}^{-3}$, and in group $\mathrm{H}_{\mathrm{I}}$ it was $0.61 \mathrm{~kg} \mathrm{~m}^{-3}$. The feed pellet sizes used in the experiments were $0.5-1.0 \mathrm{~mm}$ for group F1 and 0.9-1.6 mm for group F2. In experiment II, the pikeperch (102 $\mathrm{DPH})$ had BW $\mathrm{i}$ of $5.1 \pm 0.2 \mathrm{~g}$, and body length of $7.5 \pm$ $0.5 \mathrm{~cm}$. The stocking densities in groups $\mathrm{L}_{\mathrm{II}}$ and $\mathrm{H}_{\mathrm{II}}$ were 300 individuals per tank, while the feed pellet sizes were 0.9-1.6 mm for group F2 and 1.3-2.0 mm for group F3. The stocking densities were 1.63 and $2.13 \mathrm{~kg} \mathrm{~m}^{-3}$ in groups $\mathrm{L}_{\text {II }}$ and $\mathrm{H}_{\text {II }}$, respectively. In experiment III, the pikeperch (137 DPH) had a $\mathrm{BW}_{\mathrm{i}}$ of $16.6 \pm 0.5 \mathrm{~g}$ and a body length of $11.0 \pm 0.5 \mathrm{~cm}$. The stocking density in tanks $\mathrm{L}_{\text {III }}$ and $\mathrm{H}_{\text {III }}$ was 200 individuals each. Feed pellet size was 1.3-2.0 mm for group F3, and 1.6-2.4 mm for group F4. The stocking density in the group $\mathrm{L}_{\text {III }}$ was $3.55 \mathrm{~kg} \mathrm{~m}^{-3}$, and in group $\mathrm{H}_{\text {III }}$ it was $4.61 \mathrm{~kg} \mathrm{~m}^{-3}$. Each experiment included 12 square, gray tanks ( 2 feed pellet sizes $\times 2$ water levels $\times 3$ replicates). The water volume in the tanks with a water level of $0.65 \mathrm{~m}$ was $0.936 \mathrm{~m}^{3}(1.2 \mathrm{~m} \times 1.2 \mathrm{~m} \times$ $0.65 \mathrm{~m})$, and in the tanks with a water level of $0.5 \mathrm{~m}$, it was $0.720 \mathrm{~m}^{3}(1.2 \mathrm{~m} \times 1.2 \mathrm{~m} \times 0.50 \mathrm{~m})$. The duration of each experiment was 28 days. The fish were exposed to continuous illumination provided by fluorescent light, and the light intensity at the water surface in the rearing tanks was 200-340 lx.

\section{Measurements of physicochemical water parameters and feeding}

Oxygen content and $\mathrm{pH}$ were determined with a CyberScan PCD 5500 meter (Eutech Instruments, USA). Total ammonia nitrogen (TAN $=\mathrm{NH}_{4}{ }^{+}-\mathrm{N}+$ $\mathrm{NH}_{3}-\mathrm{N}$ ) and nitrite concentrations were determined using a spectrophotometer (Aquamate UV-Vis Plus, Thermo Scientific, England). The water quality parameters were measured at least once per week, while water temperature was measured every day. Mean water temperature was $20.8 \pm 0.5^{\circ} \mathrm{C}$ for experiment $\mathrm{I}$, 
Table 2

Basic composition (\% of dry mass), energy concentration ( $\mathrm{MJ} \mathrm{kg}^{-1}$ ), and feed pellet size (mm) used in the experiments (manufacturer's data)

\begin{tabular}{|c|c|c|c|c|}
\hline & $\mathrm{F} 1$ & F2 & F3 & $\mathrm{F} 4$ \\
\hline Protein & 56 & 54 & 54 & 54 \\
\hline Fat & 11 & 15 & 15 & 15 \\
\hline Carbohydrates & 14.5 & 13.0 & 13.0 & 13.0 \\
\hline Ash & 9.0 & 8.5 & 8.5 & 8.5 \\
\hline Fiber & 1.5 & 1.5 & 1.5 & 1.5 \\
\hline Gross Energy of feed & 20.3 & 21.1 & 21.1 & 21.1 \\
\hline Digestible energy of feed & 18.1 & 19.1 & 19.1 & 19.1 \\
\hline Pellet size & $0.5-1.0$ & $0.9-1.6$ & $1.3-2.0$ & $1.6-2.4$ \\
\hline
\end{tabular}

$22.6 \pm 0.4^{\circ} \mathrm{C}$ for experiment II, and $21.7 \pm 0.7^{\circ} \mathrm{C}$ for experiment III. Oxygen concentration in the water from the outflow of the rearing tank did not decrease below $7.2 \mathrm{mg} \mathrm{O}_{2} \mathrm{l}^{-1}$, and $\mathrm{pH}$ values ranged from 7.6 to 7.9. The maximum concentrations of ammonia nitrogen and nitrites did not exceed $0.4 \mathrm{mg} \mathrm{l}^{-1}$ or $0.1 \mathrm{mg}$ $\mathrm{l}^{-1} \mathrm{NO}_{2} \mathrm{~N}$, respectively. Water flow was $91 \mathrm{~min}^{-1}$ in experiment I and $121 \mathrm{~min}^{-1}$ in experiments II and III.

The daily feed ration was determined according to previous studies (Kozłowski et al. 2010, 2014) at $4 \%$ of fish biomass per day for experiment I, 3\% for experiment II, and 2\% for experiment III. The fish were fed Aller Performa Ex (Aller Aqua, Denmark) commercial sinking feeds (Table 2). The feed was delivered with automatic belt feeders (Fischtechnik $\mathrm{GmbH}$, Germany) for $18 \mathrm{~h} \mathrm{~d}^{-1}$. The feed ration was changed weekly after monitoring measurements.

\section{Data collection and statistical analysis}

All the fish from each tank were weighed at the beginning and the end of the experiments to determine fish biomass. Additionally, 20 fish from each tank were measured for individual body length $( \pm 1 \mathrm{~mm})$ and body weight $( \pm 0.1 \mathrm{~g})$. To determine fish growth rates and weekly feed rations, individual measurements of fish body length and body weight were taken every seven days for 20 individuals from each experimental group. Before the measurements, the fish were anesthetized in a solution of Propiscin (active substance etomidate, Kazuń and Siwicki 2001) at a concentration of $1 \mathrm{ml} \mathrm{l}^{-1}$ of water. After the completion of the experiments, the following rearing indices were calculated: specific growth rate SGR $=100(\mathrm{ln}$ $\left.\mathrm{BW}_{\mathrm{f}}-\ln \mathrm{BW}_{\mathrm{i}}\right) \mathrm{t}^{-1}$; feed conversion ratio $\mathrm{FCR}=\mathrm{TFC}$ $(\mathrm{FB}-\mathrm{IB})^{-1}$; condition factor $\mathrm{F}=100 \mathrm{BW} \mathrm{SL}^{-3}$; body weight variation coefficient $\mathrm{V}=100\left(\mathrm{SD} \mathrm{BW}_{\mathrm{m}}{ }^{-1}\right)$; survival $\mathrm{S}=100\left(\mathrm{FN} \mathrm{IN}^{-1}\right)$; where: $\mathrm{BW}_{\mathrm{i}}$ and $\mathrm{BW}_{\mathrm{f}}-$ initial and final body weight (g); BW - body weight (g); $\mathrm{BW}_{\mathrm{m}}$ - mean body weight (g); SL - standard length $(\mathrm{cm}) ; \mathrm{t}$ experiment duration (days); TFC - total feed consumption (g); SD - body weight standard deviation; IB and FB - initial and final fish biomass (g); IN and FN initial and final number of fish (ind.). All individuals were counted at the end of the experiment and the differences between the initial numbers of pikeperch and the final numbers of alive and dead pikeperch were determined to be the result of type II cannibalism.

The results are presented as mean values \pm standard deviation (SD). The uniformity of variance was verified with Levene's test. Before statistical analyses, values expressed in percentages were transformed with the arcsin function. Single factor analysis of variance (ANOVA) and Tukey's test (HSD) were applied to determine the significance of differences among the mean values of rearing indicators in the groups analyzed. Additionally, pikeperch growth data for the three initial sizes were analyzed with two-factor analysis of variance (two food pellet sizes and two water level). The differences were considered statistically 
Table 3

Final rearing parameters of pikeperch (S. lucioperca) with an initial body weight of $1.1 \mathrm{~g}$ in experiment I (group $\mathrm{L}_{\mathrm{I}}-\mathrm{F} 1$ - water level $0.5 \mathrm{~m}$ and pellet size $0.5-1.0 \mathrm{~mm}$; group $\mathrm{H}_{\mathrm{I}}-\mathrm{F} 1$ - water level $0.65 \mathrm{~m}$ and pellet size $0.5-1.0 \mathrm{~mm}$; group $\mathrm{L}_{\mathrm{I}}-\mathrm{F} 2-\mathrm{water}_{\mathrm{fevel}} 0.5 \mathrm{~m}$ and pellet size $0.9-1.6 \mathrm{~mm}$; group $\mathrm{H}_{\mathrm{I}}-\mathrm{F} 2$ - water level $0.65 \mathrm{~m}$ and pellet size $0.9-1.6 \mathrm{~mm}$ )

\begin{tabular}{lllll}
\hline \hline Parameter & Group LI-F1 & Group HI-F1 & Group LI-F2 & Group HI-F2 $^{\mathrm{a}}$ \\
\hline \hline Body weight (BW, g) & $3.1 \pm 0.2^{\mathrm{a}}$ & $3.7 \pm 0.3^{\mathrm{a}}$ & $4.9 \pm 0.3^{\mathrm{b}}$ & $5.0 \pm 0.5^{\mathrm{b}}$ \\
Total length (TL, cm) & $7.5 \pm 0.1^{\mathrm{a}}$ & $7.7 \pm 0.2^{\mathrm{a}}$ & $8.4 \pm 0.2^{\mathrm{b}}$ & $8.4 \pm 0.2^{\mathrm{b}}$ \\
Standard length (SL, cm) & $6.5 \pm 0.1^{\mathrm{a}}$ & $6.8 \pm 0.1^{\mathrm{a}}$ & $7.4 \pm 0.2^{\mathrm{b}}$ & $7.4 \pm 0.2^{\mathrm{b}}$ \\
Specific growth rate (SGR, \% d $\left.{ }^{-1}\right)$ & $3.74 \pm 0.36^{\mathrm{a}}$ & $4.24 \pm 0.30^{\mathrm{a}}$ & $5.33 \pm 0.18^{\mathrm{b}}$ & $5.35 \pm 0.34^{\mathrm{b}}$ \\
Feed conversion ratio (FCR) & $1.00 \pm 0.12^{\mathrm{a}}$ & $0.89 \pm 0.07^{\mathrm{a}}$ & $0.71 \pm 0.03^{\mathrm{b}}$ & $0.60 \pm 0.14^{\mathrm{b}}$ \\
Condition factor (CF) & $1.11 \pm 0.03^{\mathrm{a}}$ & $1.15 \pm 0.00^{\mathrm{a}}$ & $1.18 \pm 0.01^{\mathrm{b}}$ & $1.22 \pm 0.03^{\mathrm{b}}$ \\
Body weight variation coefficient (V, \%) & $26.7 \pm 4.9^{\mathrm{a}}$ & $22.3 \pm 4.3^{\mathrm{a}}$ & $32.0 \pm 8.0^{\mathrm{a}}$ & $31.6 \pm 2.1^{\mathrm{a}}$ \\
Survival (S, \%) & $93.0 \pm 2.3^{\mathrm{b}}$ & $87.1 \pm 1.1^{\mathrm{a}}$ & $88.5 \pm 1.6^{\mathrm{a}}$ & $86.7 \pm 1.4^{\mathrm{a}}$ \\
Cannibalism (\%) & $1.1 \pm 1.9^{\mathrm{b}}$ & $6.4 \pm 1.5^{\mathrm{a}}$ & $6.3 \pm 1.4^{\mathrm{a}}$ & $6.4 \pm 0.5^{\mathrm{a}}$ \\
\hline \hline
\end{tabular}

See "Materials and methods" for more details. All data are expressed as mean \pm SD. Groups marked with the same letter index in the same row do not differ statistically significantly $(\mathrm{P}>0.05)$

significant at $\mathrm{P} \leq 0.05$. The statistical calculations were performed with STATISTICA 12 PL (StatSoft, Poland).

\section{Results}

\section{Experiment I}

Single factor analysis of variance (ANOVA) and Tukey's test (HSD) showed no effect of tank water level, but showed an effect of feed pellet size. The highest growth was noted for the group of fish fed larger feed pellets. The body weight of pikeperch was higher in groups $\mathrm{H}_{\mathrm{I}}-\mathrm{F} 2(5.0 \pm 0.5 \mathrm{~g})$ and $\mathrm{L}_{\mathrm{I}}-\mathrm{F} 2(4.9 \pm$ $0.3 \mathrm{~g})$ than in groups $\mathrm{H}_{\mathrm{I}}-\mathrm{F} 1(3.7 \pm 0.3 \mathrm{~g})$ and $\mathrm{L}_{\mathrm{I}}-\mathrm{F} 1$ $(3.1 \pm 0.2 \mathrm{~g})$ (Fig. 1). Similar trends were observed in the mean total lengths and body lengths of pikeperch in all the groups (Table 3). The specific growth rate (SGR) in groups $\mathrm{H}_{\mathrm{I}}-\mathrm{F} 2$ and $\mathrm{L}_{\mathrm{I}}-\mathrm{F} 2$ was $5.3 \% \mathrm{~d}^{-1}$ and differed significantly from the group fed the smaller pellet size, regardless of tank water level. During the experiment, the feed conversion ratio (FCR) was the lowest in group $\mathrm{H}_{\mathrm{I}}-\mathrm{F} 2(0.60 \pm 0.14)$ and the highest in group $\mathrm{L}_{\mathrm{I}} \mathrm{F} 1(1.00 \pm 0.12)$. The condition factor in groups $\mathrm{H}_{\mathrm{I}}-\mathrm{F} 2$ and $\mathrm{L}_{\mathrm{I}}-\mathrm{F} 2$ fed the larger feed pellet size differed significantly from groups $\mathrm{H}_{\mathrm{I}}-\mathrm{F} 1$ and $\mathrm{L}_{\mathrm{I}}-\mathrm{F} 1(\mathrm{P}$
$<0.05$, Table 3). The body weight variation coefficient (V) and survival did not differ significantly among the groups analyzed ( $\mathrm{P}>0.05$, Table 3$)$. Cannibalism type II was significantly lower in group $\mathrm{L}_{\mathrm{I}} \mathrm{F} 1 \mathrm{(1.1 \% )}$ in comparison with the other three groups (6.4\%).

\section{Experiment II}

Pikeperch growth depended on feed pellet size and tank water level. The highest mean fish growth was recorded in groups $\mathrm{L}_{\mathrm{II}}-\mathrm{F} 3(14.6 \pm 0.9 \mathrm{~g}), \mathrm{H}_{\mathrm{II}}-\mathrm{F} 3$ (14.5 $\pm 0.5 \mathrm{~g})$, and $\mathrm{H}_{\mathrm{II}}-\mathrm{F} 2(14.2 \pm 0.6 \mathrm{~g})$, and it differed significantly from that in group $\mathrm{L}_{\mathrm{II}}-\mathrm{F} 2(11.7 \pm 0.2 \mathrm{~g})(\mathrm{P}<$ 0.05, Fig. 2). The final total length (TL) was longer in these three groups $(12.1 \mathrm{~cm})$ than in group $\mathrm{L}_{\mathrm{II}}-\mathrm{F} 2$ $(11.4 \pm 0.1 \mathrm{~cm})$. The same trend was observed in the mean pikeperch standard length in all groups (Table 4). The SGR was higher in groups $\mathrm{L}_{\mathrm{II}}-\mathrm{F} 3$ (3.70 \pm 0.17), $\mathrm{H}_{\mathrm{II}} \mathrm{F} 3(3.69 \pm 0.13)$, and $\mathrm{H}_{\mathrm{II}} \mathrm{F} 2(3.63 \pm 0.20)$ than in group $\mathrm{L}_{\mathrm{II}} \mathrm{F} 2(3.06 \pm 0.08)$. The lowest FCR was noted in group $\mathrm{H}_{\mathrm{II}} \mathrm{F} 2(0.74 \pm 0.04)$, while the highest was in group $\mathrm{L}_{\mathrm{II}} \mathrm{F} 2(0.85 \pm 0.01)(\mathrm{P}<0.05)$. The final body weight variation coefficient was the lowest in group $\mathrm{H}_{\mathrm{II}}-\mathrm{F} 3(17.3 \pm 0.7 \%)$ and differed significantly from the other groups analyzed. Survival (96.1\% to $98.7 \%)$ and cannibalism (0.2 to $1.6 \%)$ did 


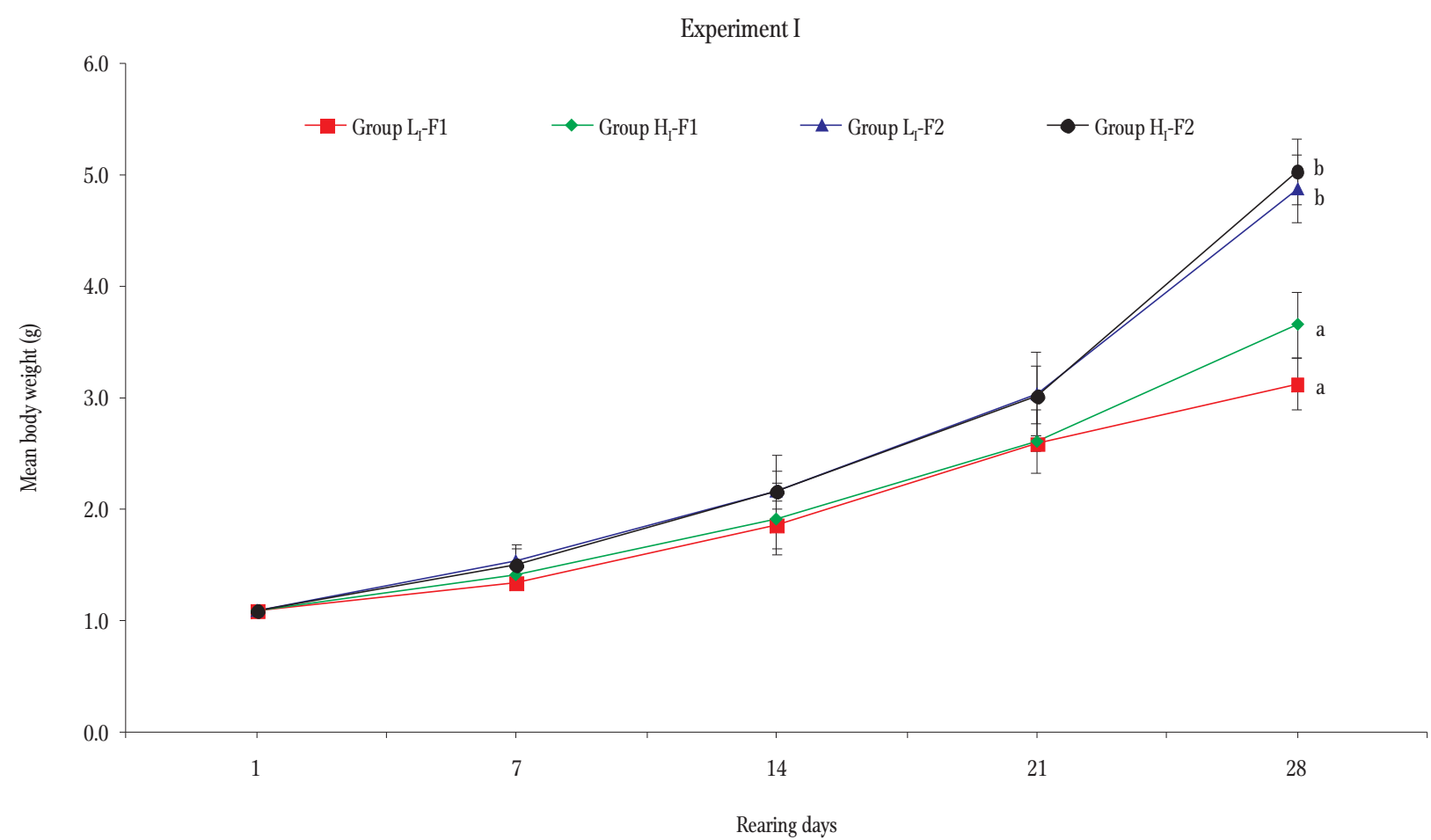

Figure 1. Changes in the body weight of pikeperch (S. lucioperca) in groups $\mathrm{L}_{\mathrm{I}}-\mathrm{F} 1$ (water level $0.5 \mathrm{~m}$ and pellet size $0.5-1.0 \mathrm{~mm}$ ), $\mathrm{H}_{\mathrm{I}}-\mathrm{F} 1$ (water level $0.65 \mathrm{~m}$ and pellet size $0.5-1.0 \mathrm{~mm}$ ), $\mathrm{L}_{\mathrm{I}}-\mathrm{F} 2$ (water level $0.5 \mathrm{~m}$ and pellet size $0.9-1.6 \mathrm{~mm}$ ), and $\mathrm{H}_{\mathrm{I}}-\mathrm{F} 2$ (water level $0.65 \mathrm{~m}$ and pellet size $0.9-1.6 \mathrm{~mm}$ ) over the course of experiment I. Mean values from three replicates \pm standard deviations. Values marked with different letters indicate significant differences $(\mathrm{P}<0.05)$.

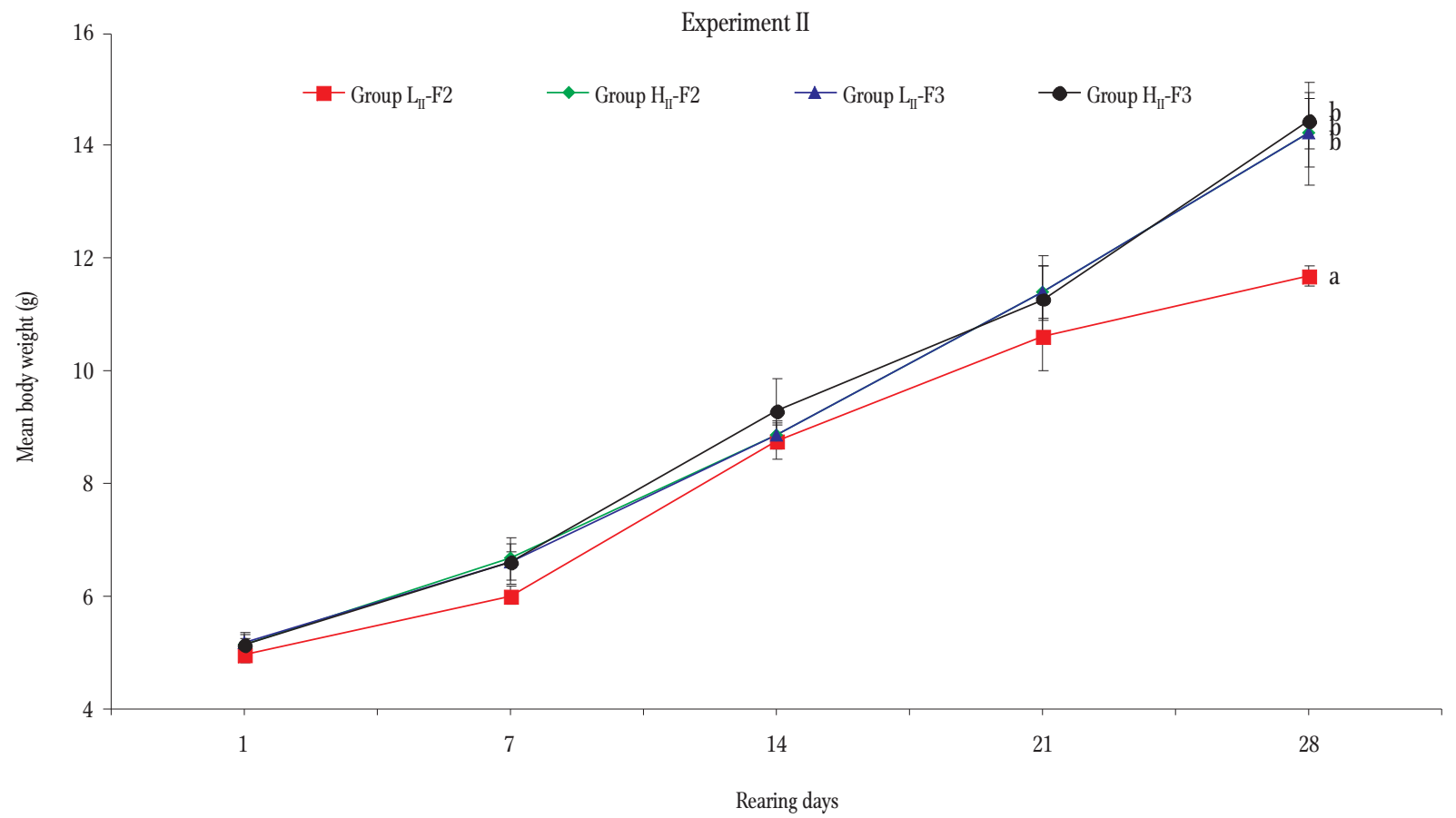

Figure 2. Changes in the body weight of pikeperch (S. lucioperca) in groups $\mathrm{L}_{\mathrm{II}}-\mathrm{F} 2$ (water level $0.5 \mathrm{~m}$ and pellet size $0.9-1.6 \mathrm{~mm}$ ), $\mathrm{H}_{\mathrm{II}}-\mathrm{F} 2$ (water level $0.65 \mathrm{~m}$ and pellet size $0.9-1.6 \mathrm{~mm}$ ), $\mathrm{L}_{\mathrm{II}}-\mathrm{F} 3$ (water level $0.5 \mathrm{~m}$ and pellet size $1.3-2.0 \mathrm{~mm}$ ), and $\mathrm{H}_{\mathrm{II}}-\mathrm{F} 3$ (water level $0.65 \mathrm{~m}$ and pellet size 1.3-2.0 mm) over the course of experiment II. Mean values from three replicates \pm standard deviations. Values marked with different letters indicate significant differences $(\mathrm{P}<0.05)$. 
Table 4

Final rearing parameters of pikeperch (S. lucioperca) with an initial body weight of $5.1 \mathrm{~g}$ in experiment II (group LII-F2 - water level $0.5 \mathrm{~m}$ and pellet size $0.9-1.6 \mathrm{~mm}$; group $\mathrm{H}_{\mathrm{II}}-\mathrm{F} 2$ - water level $0.65 \mathrm{~m}$ and pellet size $0.9-1.6 \mathrm{~mm}$; group $\mathrm{L}_{\mathrm{II}}-\mathrm{F} 3-\mathrm{water}$ level $0.5 \mathrm{~m}$ and pellet size $1.3-2.0 \mathrm{~mm}$; group $\mathrm{H}_{\mathrm{II}} \mathrm{F} 3$ - water level $0.65 \mathrm{~m}$ and pellet size $1.3-2.0 \mathrm{~mm}$ )

\begin{tabular}{lllll}
\hline \hline Parameter & Group LII-F2 & Group HII-F2 & Group L LI-F3 & Group HII-F3 \\
\hline \hline Body weight (BW, g) & $11.7 \pm 0.2^{\mathrm{a}}$ & $14.2 \pm 0.6^{\mathrm{b}}$ & $14.6 \pm 0.9^{\mathrm{b}}$ & $14.5 \pm 0.5^{\mathrm{b}}$ \\
Total length (TL, cm) & $11.4 \pm 0.1^{\mathrm{a}}$ & $12.1 \pm 0.2^{\mathrm{b}}$ & $12.1 \pm 0.3^{\mathrm{b}}$ & $12.1 \pm 0.2^{\mathrm{b}}$ \\
Standard length (SL, cm) & $9.9 \pm 0.1^{\mathrm{a}}$ & $10.5 \pm 0.2^{\mathrm{b}}$ & $10.5 \pm 0.2^{\mathrm{b}}$ & $10.5 \pm 0.2^{\mathrm{b}}$ \\
Specific growth rate (SGR, \% d $\left.{ }^{-1}\right)$ & $3.06 \pm 0.08^{\mathrm{a}}$ & $3.63 \pm 0.20^{\mathrm{b}}$ & $3.70 \pm 0.17^{\mathrm{b}}$ & $3.69 \pm 0.13^{\mathrm{b}}$ \\
Feed conversion ratio (FCR) & $0.85 \pm 0.01^{\mathrm{a}}$ & $0.74 \pm 0.04^{\mathrm{b}}$ & $0.76 \pm 0.02^{\mathrm{b}}$ & $0.75 \pm 0.03^{\mathrm{b}}$ \\
Condition factor (CF) & $1.20 \pm 0.03^{\mathrm{a}}$ & $1.22 \pm 0.02^{\mathrm{a}}$ & $1.24 \pm 0.01^{\mathrm{a}}$ & $1.25 \pm 0.03^{\mathrm{a}}$ \\
Body weight variation coefficient (V, \%) & $24.2 \pm 4.4^{\mathrm{a}}$ & $26.8 \pm 5.7^{\mathrm{a}}$ & $28.6 \pm 0.7^{\mathrm{a}}$ & $17.3 \pm 0.7^{\mathrm{b}}$ \\
Survival (S, \%) & $98.6 \pm 0.7^{\mathrm{a}}$ & $96.9 \pm 1.0^{\mathrm{a}}$ & $96.1 \pm 2.5^{\mathrm{a}}$ & $98.7 \pm 1.2^{\mathrm{a}}$ \\
Cannibalism (\%) & $0.4 \pm 0.8^{\mathrm{a}}$ & $1.6 \pm 1.1^{\mathrm{a}}$ & $1.6 \pm 1.4^{\mathrm{a}}$ & $0.2 \pm 0.4^{\mathrm{a}}$ \\
\hline \hline
\end{tabular}

For more details, see "Materials and methods". All data are expressed as mean \pm SD. Groups marked with the same letter index in the same row do not differ statistically significantly $(\mathrm{P}>0.05)$.

Table 5

Final rearing parameters of pikeperch (S. lucioperca) with an initial body weight of $16.6 \mathrm{~g}$ in experiment III (group L $\mathrm{L}_{\mathrm{III}}-\mathrm{F} 3$ - water level $0.5 \mathrm{~m}$ and pellet size $1.3-2.0 \mathrm{~mm}$; group $\mathrm{H}_{\mathrm{III}}-\mathrm{F} 3$ - water level $0.65 \mathrm{~m}$ and pellet size $1.3-2.0 \mathrm{~mm}$; group $\mathrm{L}_{\mathrm{III}}-\mathrm{F} 4$ - water level $0.5 \mathrm{~m}$ and pellet size $1.6-2.4 \mathrm{~mm}$; group $\mathrm{H}_{\mathrm{III}} \mathrm{F} 4$ - water level $0.65 \mathrm{~m}$ and pellet size $1.6-2.4 \mathrm{~mm}$ )

\begin{tabular}{|c|c|c|c|c|}
\hline Parameter & Group $\mathrm{L}_{\mathrm{III}}-\mathrm{F} 3$ & Group $\mathrm{H}_{\mathrm{III}} \mathrm{F} 3$ & Group $\mathrm{L}_{\mathrm{III}}-\mathrm{F} 4$ & Group $\mathrm{H}_{\mathrm{II}} \mathrm{I}-\mathrm{F} 4$ \\
\hline Body weight (BW, g) & $33.6 \pm 0.7^{\mathrm{a}}$ & $36.2 \pm 0.3^{b}$ & $34.8 \pm 0.3^{\mathrm{a}}$ & $36.0 \pm 0.9^{b}$ \\
\hline Total length (TL, cm) & $16.4 \pm 0.3^{\mathrm{a}}$ & $16.7 \pm 0.2^{\mathrm{a}}$ & $16.5 \pm 0.1^{\mathrm{a}}$ & $16.7 \pm 0.1^{\mathrm{a}}$ \\
\hline Standard length (SL, cm) & $14.1 \pm 0.3^{\mathrm{a}}$ & $14.5 \pm 0.2^{\mathrm{a}}$ & $14.1 \pm 0.1^{\mathrm{a}}$ & $14.5 \pm 0.1^{\mathrm{a}}$ \\
\hline Specific growth rate (SGR, $\left.\% \mathrm{~d}^{-1}\right)$ & $2.54 \pm 0.06^{\mathrm{a}}$ & $2.81 \pm 0.15^{b}$ & $2.63 \pm 0.05^{\mathrm{ab}}$ & $2.73 \pm 0.06^{\mathrm{ab}}$ \\
\hline Feed conversion ratio (FCR) & $0.71 \pm 0.02^{\mathrm{a}}$ & $0.67 \pm 0.05^{\mathrm{a}}$ & $0.72 \pm 0.01^{\mathrm{a}}$ & $0.70 \pm 0.00^{\mathrm{a}}$ \\
\hline Condition factor $(\mathrm{CF})$ & $1.26 \pm 0.07^{\mathrm{a}}$ & $1.30 \pm 0.03^{\mathrm{a}}$ & $1.28 \pm 0.04^{\mathrm{a}}$ & $1.23 \pm 0.04^{\mathrm{a}}$ \\
\hline Body weight variation coefficient (V, \%) & $25.5 \pm 7.8^{\mathrm{a}}$ & $17.9 \pm 1.9^{\mathrm{a}}$ & $23.7 \pm 3.2^{\mathrm{a}}$ & $17.5 \pm 2.8^{\mathrm{a}}$ \\
\hline Survival (S, \%) & $99.2 \pm 1.0^{\mathrm{a}}$ & $98.8 \pm 0.8^{\mathrm{a}}$ & $98.2 \pm 1.9^{\mathrm{a}}$ & $99.3 \pm 0.6^{\mathrm{a}}$ \\
\hline Cannibalism (\%) & $0.5 \pm 0.9^{\mathrm{a}}$ & $1.2 \pm 0.8^{\mathrm{a}}$ & $1.7 \pm 1.6^{\mathrm{a}}$ & $0.2 \pm 0.3^{\mathrm{a}}$ \\
\hline
\end{tabular}

For more details, see "Materials and methods". All data are expressed as mean \pm SD. Groups marked with the same letter index in the same row do not differ statistically significantly $(\mathrm{P}>0.05)$

not differ significantly among the groups analyzed $(\mathrm{P}>0.05$, Table 4).

\section{Experiment III}

The highest body weights were noted for the groups of fish reared in the tanks with a higher water level $(0.65 \mathrm{~m})$ irrespective of the applied feed pellet size ( $\mathrm{H}_{\text {III-F3 }}$ and $\left.\mathrm{H}_{\text {III- }} \mathrm{F} 4\right)$. The average body weight was greater in groups $\mathrm{H}_{\mathrm{III}}-\mathrm{F} 3(36.2 \pm 0.3 \mathrm{~g})$ and $\mathrm{H}_{\mathrm{III}}-\mathrm{F} 4$ $(36.0 \pm 0.9 \mathrm{~g})$ than in groups $\mathrm{L}_{\mathrm{III}}-\mathrm{F} 4(34.8 \pm 0.3 \mathrm{~g})$ and $\mathrm{L}_{\mathrm{III}}-\mathrm{F} 3$ (33.6 $\pm 0.7 \mathrm{~g}$ ) (Fig. 3). The SGR was the highest in group $\mathrm{H}_{\mathrm{III}} \mathrm{F} 3\left(2.81 \pm 0.15 \% \mathrm{~d}^{-1}\right)$ and differed significantly from group $\mathrm{L}_{\mathrm{III}} \mathrm{F} 3(2.54 \pm 0.06)$ $(\mathrm{P}<0.05)$. The lowest FCR was noted in group $\mathrm{H}_{\text {III-F3 }}$ (0.67 \pm 0.05$)$, while the highest was in group $\mathrm{L}_{\mathrm{III}}-\mathrm{F} 4(0.85 \pm 0.01)(\mathrm{P}>0.05)$. There were no significant differences in the other parameters $(\mathrm{P}>0.05$, Table 5). 


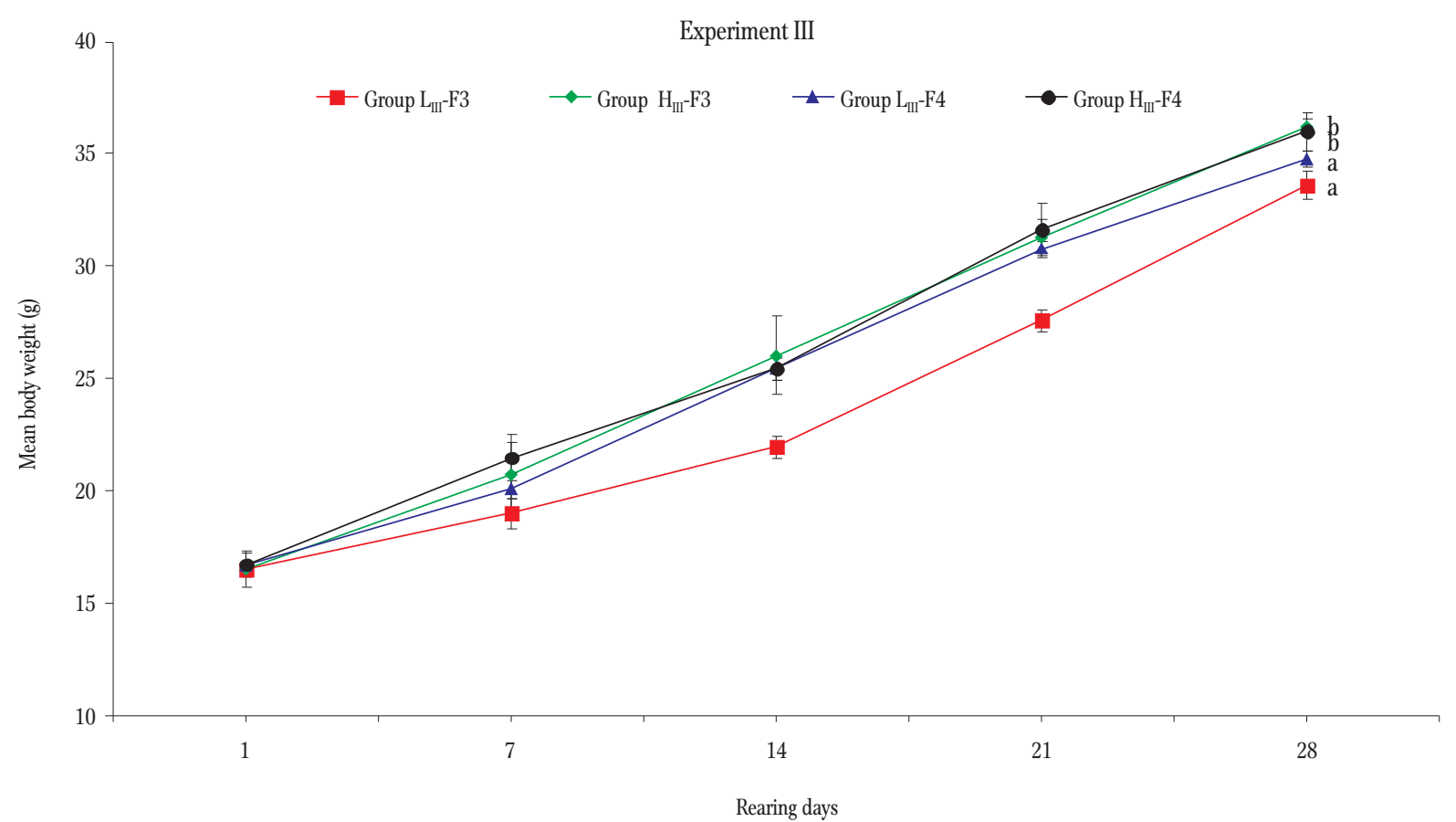

Fig. 3. Changes in the body weight of pikeperch (S. lucioperca) in groups $\mathrm{L}_{\mathrm{III}}-\mathrm{F} 3$ (water level $0.5 \mathrm{~m}$ and pellet size $1.3-2.0 \mathrm{~mm}$ ), $\mathrm{H}_{\mathrm{III}}-\mathrm{F} 3$ (water level $0.65 \mathrm{~m}$ and pellet size $1.3-2.0 \mathrm{~mm}$ ), $\mathrm{L}_{\mathrm{III}}-\mathrm{F} 4$ (water level $0.5 \mathrm{~m}$ and pellet size $1.6-2.4 \mathrm{~mm}$ ), and $\mathrm{H}_{\text {III }}-\mathrm{F} 4$ (water level $0.65 \mathrm{~m}$ and pellet size 1.6-2.4 mm) over the course of experiment III. Mean values from three replicates \pm standard deviations. Values marked with different letters indicate significant differences $(\mathrm{P}<0.05)$.

\section{Relationships between pikeperch growth and feed pellet size and tank water level}

Two-factor analysis of variance showed that the growth of pikeperch of an initial body weight of $1.1 \mathrm{~g}$ was significantly dependent on feed pellet size $(\mathrm{P}=0.0000)$. However, no relationships were noted between the applied feed pellet size and tank water level (Table 6). The growth of pikeperch of an initial body weight of $5.1 \mathrm{~g}$ was positively correlated both with feed pellet size $(P=0.0023)$ and water level $(\mathrm{P}=0.0086)$. A significant correlation was also observed between the applied feed pellet size and water level $(\mathrm{P}=0.0057)$. In experiment III, a significant relationship was found between pikeperch growth and water level $(\mathrm{P}=0.0004)$. No interaction was observed between the applied feed pellet size and tank water level $(\mathrm{P}>0.05)$.

Table 6

Growth of pikeperch (S. lucioperca) of three initial sizes using different feed pellet sizes at two tank water levels after 28 days of rearing (mean values and ranges in parentheses)

\begin{tabular}{|c|c|c|c|c|c|c|}
\hline \multirow{2}{*}{ Water level } & \multicolumn{2}{|c|}{ Experiment I (BW $1.1 \mathrm{~g})$} & \multicolumn{2}{|c|}{ Experiment II (BW $5.1 \mathrm{~g})$} & \multicolumn{2}{|c|}{ Experiment III (BW $\left.{ }_{\mathrm{i}} 16.6 \mathrm{~g}\right)$} \\
\hline & Feed - F1 & Feed - F2 & Feed - F2 & Feed - F3 & Feed - F3 & Feed - F4 \\
\hline $0.65 \mathrm{~m}$ & $3.7(3.3-3.9)$ & $5.0(4.5-5.4)$ & $14.2(13.7-14.9)$ & $14.5(13.9-15.0)$ & $36.2(35.9-36.5)$ & $36.0(35.3-36.9)$ \\
\hline $0.50 \mathrm{~m}$ & $3.1(2.9-3.3)$ & $4.9(4.6-5.0)$ & $11.7(11.6-11.9)$ & $14.6(13.9-15.6)$ & $33.6(32.9-34.1)$ & $34.8(34.5-35.2)$ \\
\hline \multicolumn{7}{|l|}{ MANOVA } \\
\hline Source & $\mathrm{F}$ & $\mathrm{P}$ & $\mathrm{F}$ & $\mathrm{P}$ & $\mathrm{F}$ & $\mathrm{P}$ \\
\hline Pellet size (P) & 67.08 & 0.0000 & 19.15 & 0.0023 & 1.85 & 0.2109 \\
\hline Tank water level (L) & 3.19 & 0.1118 & 11.92 & 0.0086 & 32.11 & 0.0004 \\
\hline $\mathrm{P} \times \mathrm{L}$ & 1.01 & 0.3454 & 13.96 & 0.0057 & 4.35 & 0.0705 \\
\hline
\end{tabular}

Abbreviations: $\mathrm{BW}_{\mathrm{i}}$ - initial body weight 


\section{Discussion}

The results of our experiments showed that both feed pellet size and tank water level affected juvenile pikeperch growth considerably. In experiment I, faster fish growth was mainly due to larger feed pellet size regardless of tank water level. In experiment II, fish growth depended on both feed pellet size and tank water level. In experiment III, pikeperch growth was primarily associated with tank water level since it was the fastest in the tanks with water levels of 0.65 $m$ irrespective of feed pellet size.

The values of SGR obtained in experiment I were similar to those published by Molnár et al. (2004) for juvenile pikeperch with an initial body weight of 0.91 $\mathrm{g}$ at $23.0^{\circ} \mathrm{C}$. The $\mathrm{SGR}$ values in experiment II $\left(3.06-3.70 \% \mathrm{~d}^{-1}\right)$ were higher than those reported by Kozłowski et al. (2010) for fish with a BW $\mathrm{BW}_{\mathrm{i}}$ of $4.4 \mathrm{~g}$ (SGR 2.62-2.70 \% d $\mathrm{d}^{-1}$ at $20.0^{\circ} \mathrm{C}$ ) and Wang et al. (2009) for pikeperch with a $\mathrm{BW}_{\mathrm{i}}$ of $6.4 \mathrm{~g}$ (SGR $1.2-2.0 \% \mathrm{~d}^{-1}$ at $20-28^{\circ} \mathrm{C}$ ), while they were similar to those noted by Kozłowski et al. (2014) for pikeperch with a $\mathrm{BW}_{\mathrm{i}}$ of $6.1 \mathrm{~g}$ at $24.4^{\circ} \mathrm{C}\left(\mathrm{SGR} 3.37-3.61 \% \mathrm{~d}^{-1}\right)$. In experiment III, SGR values ranged from 2.54 to $2.81 \% \mathrm{~d}^{-1}$ and were twice as high as those reported by Schulz et al. (2005) for pikeperch with a BW $\mathrm{BW}_{\mathrm{i}}$ of $15.2 \mathrm{~g}$ at $22.6^{\circ} \mathrm{C}$ (SGR $1.37-1.45 \% \mathrm{~d}^{-1}$ ). The SGR values in our research were similar to or higher than the values reported in other publications on rearing pikeperch in RAS.

Fish expend more energy when consuming smaller feed pellets, which means that feeding fish feed pellets that are too small can lead to growth inhibition stemming from, among other things, a less beneficial energy balance (Tabachek 1988, Zakęś et al. 2013). Feed pellet size can also affect digestion time, and, therefore, the absorption of nutrients from the feed. This leads to increased feeding frequency, but this does not always contribute to faster fish growth (Sveier et al. 1999, Hossain et al. 2000). Moreover, a large number of small pellets supplied too quickly can go unconsumed since there is a limit to the number of pellets fish can capture and consume (Tabachek 1988). In the current study, pikeperch of an initial body weight of $1.1 \mathrm{~g}$ grew faster when fed the larger feed pellet size. Feed F1 used in the present experiment was characterized by a lower gross feed energy compared to feed F2. In addition, feed $\mathrm{F} 1$ contained $2 \%$ more protein, $1.5 \%$ more carbohydrates, $0.5 \%$ more ash, but $4 \%$ less fat than did feed F2. Consequently, the results cannot be attributed exclusively to the influence of feed pellet size because of the slight difference in the feed micronutrient compositions. Depending on life stage, the nutritional requirements of percid fishes are met by formulated feeds containing $43-50 \%$ protein, $13-18 \%$ lipids, and $10-15 \%$ carbohydrates, which are noted to support very good growth performance when the feed is delivered either continuously or three times per day (Geay and Kestemont 2015, Policar et al. 2019). In the current experiment, the feed composition was within optimal values for rearing pikeperch.

The tank water levels used in the study resulted in different tank water volumes. The densities in all the experiments referred to a similar number of fish in each tank (individuals tank ${ }^{-1}$ ), which resulted in different stocking densities $\left(\mathrm{kg} \mathrm{m}^{-3}\right)$. In the present study, the initial stocking densities in the three experiments were low. According to Molnár et al. (2004), who reared pikeperch of an initial body weight of $0.91 \mathrm{~g}$ in three initial densities of 1.25 , 1.66 , and $2.08 \mathrm{~kg} \mathrm{~m}^{-3}$ for 4 weeks at $23^{\circ} \mathrm{C}$, stocking density did not significantly affect the growth parameters in their experiment; thus, the different stocking densities used in our study most likely also did not have a significant impact on the results we obtained.

The effect of feed pellet size on fish growth depends on the size of the fish. Feeding fish with different feed pellet sizes leads to unequal possibilities for large and small fish to feed. Large fish can rapidly and efficiently consume large pellets that have a higher energy content than do small pellets. Small fish either reject larger pellets or spend more time on gradually breaking them down for consumption. Therefore, large individuals have an energetic advantage over small ones when they feed on larger feed pellets (Nakamura and Kasahara 1955, Wańkowski and Thorpe 1979). The size advantage of larger 
individuals over smaller ones increases rapidly with time to size differences that permit larger fish to exclude smaller ones efficiently from limited, spatially concentrated feed sources, which results in even greater size differences. Therefore, pellet size can also contribute to fish body weight variations that are generally undesirable in fish culture. In the present study, the body weight variation coefficient increased with experiment duration. Only in experiment II with fish feeding on larger feed pellets in a tank with a water depth of $0.65 \mathrm{~m}$ (group $\mathrm{H}_{\mathrm{II}}-\mathrm{F} 3$ ) did this coefficient not increase. Our results differed from those obtained when rearing larger pikeperch $(>100 \mathrm{~g})$ in which larger feed pellet sizes increased final body weight variation coefficients (Zakęś et al. 2013, Mattila and Koskela 2017). The body weight variation coefficient in this study (17.3-32.0\%) was lower than those noted in other studies on pikeperch with similar initial body weights (Wang et al. 2009), but they were similar to results reported in other studies (Kozłowski et al. 2010, 2014).

According to Zakęś (1999), size variability significantly influences rearing success, especially with regard to survival. The author suggested that, when rearing pikeperch with body weights of $0.7 \mathrm{~g}$ and high heterogeneity, final survival after 8 weeks was $50 \%$, while in groups with body weights of $1.1 \mathrm{~g}$ survival was 90\% (Zakęś, unpublished data). In our study, pikeperch survival was high (> 86\%) and was due to size grading fish before each experiment and fine tuning fish culture practices. The survival rates in the current experiment were similar to values obtained in other studies on pikeperch (Schulz et al. 2005, Kozłowski et al. 2010, 2014) and higher (44-50\%) than in other studies (Molnár et al. 2004).

Some studies have shown that type II cannibalism occurs most frequently between the third and sixth week after hatching (Colchen et al. 2019). However, the time cannibalism occurs can vary depending on breeding conditions, and it is directly related to size differences among individuals (Baras 2013, Naumowicz et al. 2017). Type II cannibalism is characterized by the swallowing of the entire fish under attack, and by attacks that usually occur from the side of the head or the body of the prey (Baras and
Jobling 2002). This type of cannibalism occurred primarily in experiment I, where the initial body weight of fish was $1.1 \mathrm{~g}$. Only in the group of fish fed the smallest feed pellets in tanks with water levels of $0.5 \mathrm{~m}\left(\mathrm{~L}_{\mathrm{I}}-\mathrm{F} 1\right)$ cannibalism was significantly lower $(1.1 \%)$ in comparison to the other three groups (6.4\%). The reason for such low cannibalism in group LI-F1 could have been the smaller tank volume that limited the possibility of juvenile pikeperch demonstrating aggressive behavior (Colchen et al. 2019). In experiments II and III, the level of cannibalism was low (<1.7\%); according to Hilge and Steffens (1996), cannibalism in pikeperch stops at a length of about 5 $\mathrm{cm}$.

The tank water level $(0.65 \mathrm{~m})$ used in the present study influenced pikeperch growth significantly in experiment III, which was probably because of the longer suspension time of the feed pellets in the tank. Therefore, it is likely that this factor determined intergroup differences in pikeperch weighing over $16 \mathrm{~g}$. This is important for pikeperch because this species consumes feed immediately after its delivery at the water surface. At the lower tank water level $(0.5 \mathrm{~m})$, the fish had less time to consume the feed before it reached the bottom of the tanks. These results confirmed earlier research that tank water level significantly affects the growth rates of fish in RAS, such as pikeperch (Kozłowski et al. 2009), Atlantic salmon (Einarsdóttir and Nilssen 1996), and brown trout (Salmo trutta) (Flodmark et al. 2004). The effect of water depth was also noted with regard to the growth performance of three species of Indian major carp (Gibelion catla, Labeo rohita, Cirrhinus mrigala) (Hosen et al. 2019) and Nile tilapia (Ali et al. 2013) in ponds.

The results of our study showed that tank water level was not an important factor for small pikeperch, but it became more important with larger fish. Although feed pellet size was of minor importance for large fish, it was very important for small fish. In conclusion, the results of the present experimental study suggested that a feed pellet size of $0.9-1.6 \mathrm{~mm}$ at BWi of $1.1 \mathrm{~g}$ and $1.3-2.0 \mathrm{~mm}$ at BWi of $5.1 \mathrm{~g}$ were appropriate for achieving better pikeperch growth 
rates, while for pikeperch with a BWi of $16.6 \mathrm{~g}$, feed pellet size was less important than tank water level.

Acknowledgements. The study was conducted within the framework of the statutory research program of the Inland Fisheries Institute in Olsztyn (No. S028).

Author contributions. M.K. designed the research; M.K, I.P. and B.S. performed the research; M.K., I.P and B.S. analysed the data; M.K wrote the paper.

\section{ORCID iD}

Michał Kozłowski (iD https://orcid.org/0000-0001-7769-7051 Iwona Piotrowska iD https://orcid.org/0000-0002-0495-3568

Bożena Szczepkowska (iD https://orcid.org/0000-0002-0164-4647

\section{References}

Abdel-Hay, A. H. M., Emam, W., Omar, A. A., Eltras, W. F., Mohamed, R. A. (2020). The effects of rearing water depths and feed types on the growth performance of African catfish (Clarias gariepinus). Aquaculture Research, 51(2), 616-622.

Ali, M. A. M., El-Feky, A. M. I., Khouraiba, H. M., El-Sherif, M. S. (2013). Effect of water depth on growth performance and survival rate of mixed sex Nile tilapia fingerlings and adults. Egyptian Journal of Animal Production, 50(3), 194-199.

Azaza, M. S., Dhraief, M. N., Kraiem, M. M., Baras, E. (2010). Influences of food particle size on growth, size heterogeneity, food intake and gastric evacuation in juvenile Nile tilapia, Oreochromis niloticus, L., 1758. Aquaculture, 309(1-4), 193-202.

Baras, E. (2013) Cannibalism in fish larvae: What have we learned? In: Larval fish aquaculture (Ed.) Qin J. G., Nova Science Publishers, New York,167-199.

Baras, E., Jobling, M. (2002). Dynamics of intracohort cannibalism in cultured fish. Aquaculture Research, 33(7), 461-479.

Bucat, T., Saraoğlu, E., Levi, E.E., Nihan Tavşanoğlu, U., İdil Çakiroğlu, A., Jeppesen, E., Beklioğlu, M. (2012). The influence of water level on macrophyte growth and trophic interactions in eutrophic Mediterranean shallow lakes: a mesocosm experiment with and without fish. Freshwater Biology, 57: 1631-1642.

Colchen, T., Fontaine, P., Ledoré, Y., Teletchea, F., Pasquet, A. (2019). Intra-cohort cannibalism in early life stages of pikeperch. Aquaculture Research, 50(3), 915-924.

Dalsgaard, J., Lund, I., Thorarinsdottir, R., Drengstig, A., Arvonen, K., Pedersen, P. B. (2013). Farming different species in RAS in Nordic countries: Current status and future perspectives. Aquacultural Engineering, 53, 2-13.

Dos Santos, J., Burkow, I. C., Jobling, M. (1993). Patterns of growth and lipid deposition in cod (Gadus morhua L.) fed natural prey and fish-based feeds. Aquaculture, 110(2), 173-189.

Einarsdóttir, I. E., Nilssen, K. J. (1996). Stress responses of Atlantic salmon (Salmo salar L.) elicited by water level reduction in rearing tanks. Fish Physiology and Biochemistry, 15(5), 395-400.

El Naggar, G. O., John, G., Rezk, M. A., Elwan, W., Yehia, M. (2006). Effect of varying density and water level on the spawning response of African catfish Clarias gariepinus: Implications for seed production. Aquaculture, 261(3), 904-907.

Flodmark, L. E. W., Vøllestad, L. A., Forseth, T. (2004). Performance of juvenile brown trout exposed to fluctuating water level and temperature. Journal of Fish Biology, 65(2), 460-470.

Geay, F., Kestemont, P. (2015). Feeding and nutrition of percid fishes during ongrowing stages. In: Biology and culture of percid fishes - principles and practices (Ed.) Kestemont P., Dabrowski K., Summerfelt R. C., Springer, Dordrecht, Netherlands, 587-622.

Goldan, O., Popper, D., Karplus, I. (1997). Management of size variation in juvenile gilthead sea bream (Sparus aurata). I: Particle size and frequency of feeding dry and live food. Aquaculture, 152(1-4), 181-190.

Hilge, V., Steffens, W. (1996). Aquaculture of fry and fingerling of pike-perch (Stizostedion lucioperca L.) - a short review. Journal of Applied Ichthyology, 12(3-4), 167-170.

Hasan, M. R., Macintosh, D. J. (1992). Optimum food particle size in relation to body size of common carp, Cyprinus carpio L., fry. Aquaculture Research, 23(3), 315-325.

Hosen, M. H. A., Sarker, K., Chhanda, M. S., Gupta, N. (2019). Effects of water depth on growth performance of Indian major carps at a poly culture system in Bangladesh. International Journal of Aquaculture and Fishery Sciences, 5(3), 014-021.

Hossain, M. A. R., Haylor, G. S., Beveridge, M. C. M. (2000). The influence of food particle size on gastric emptying and growth rates of fingerling African catfish, Clarias gariepinus Burchell, 1822. Aquaculture Nutrition, 6(2), 73-76.

Kahl, U., Hülsmann, S., Radke, R. J., Benndorf, J. (2008). The impact of water level fluctuations on the year class strength of roach: Implications for fish stock management. Limnologica, 38(3-4), 258-268.

Kazuń, K., Siwicki, A. K. (2001). Propiscin - a safe new anaesthetic for fish. Archives of Polish Fisheries, 9, 183-190.

Kestemont, P., Jourdan, S., Houbart, M., Mélard, C., Paspatis, M., Fontaine, P., Cuvier, A., Kentouri, M., Baras, E. (2003). Size heterogeneity, cannibalism and competition 
in cultured predatory fish larvae: biotic and abiotic influences. Aquaculture, 227(1-4), 333-356.

Kestemont, P., Xueliang, X., Hamza, N., Maboudou, J., Toko, I. I. (2007). Effect of weaning age and diet on pikeperch larviculture. Aquaculture, 264(1-4), 197-204.

Kestemont, P., Dabrowski, K., Summerfelt, R. C. (2015). Biology and culture of percid fishes - principles and practices. Springer, Dordrecht, Netherlands.

Kozłowski, M., Szczepkowski, M., Wunderlich, K., Piotrowska, I., Szczepkowska, B., Zakęś, Z. (2009). Effect of height water column in tank on rearing indiactors pikeperch fry (Sander lucioperca), In: Reproduction, rearing, prophylactics in salmonids fish and other species. (Ed.) Zakęś Z., Demska-Zakęś K., Kowalska A., Ulikowski D., Wydawnictwo IRS, Olsztyn, 287-293 (in Polish).

Kozłowski, M., Zakęś, Z., Szczepkowski, M., Wunderlich, K., Piotrowska, I., Szczepkowska, B. (2010). Impact of light intensity on the results of rearing juvenile pikeperch, Sander lucioperca (L.), in recirculating aquaculture systems. Archives of Polish Fisheries, 18(2), 77-84.

Kozłowski, M., Szczepkowski, M., Wunderlich, K., Szczepkowska, B., Piotrowska, I. (2014). Polyculture of juvenile pikeperch (Sander lucioperca (L.)) and sterlet (Acipenser ruthenus L.) in a recirculating system. Archives of Polish Fisheries, 22(4), 237-242.

Mattila, J., Koskela, J. (2018). Effect of feed pellet size on production parameters of pike-perch (Sander lucioperca). Aquaculture Research, 49(1), 586-590.

Molnár, T., Hancz, C., Bódis, M., Müller, T., Bercsényi, M., Horn, P. (2004). The effect of initial stocking density on growth and survival of pike-perch fingerlings reared under intensive conditions. Aquaculture International, 12(2), 181-189.

Nakamura, N., Kasahara, S. (1955). A study on the phenomenon of the tobi koi or shoot carp I. On the earliest stage at which the shoot carp appears. Bulletin of the Japanese Society of Scientific Fisheries 21, 73-76.

Naumowicz, K., Pajdak, J., Terech-Majewska, E., Szarek, J. (2017). Intracohort cannibalism and methods for its mitigation in cultured freshwater fish. Reviews in Fish Biology and Fisheries, 27(1), 193-208.

Overton, J. L., Toner, D., Policar, T., Kucharczyk, D. (2015). Commercial production: factors for success and limitations in European percid fish culture. In: Biology and culture of percid fishes - principles and practices (Ed.) Kestemont P., Dabrowski K., Summerfelt R. C., Springer, Dordrecht, Netherlands, 881-890.
Pandian, T. J., Vivekanandan, E. (1985). Energetics of feeding and digestion. In: Fish Energetics: New Perspective (Ed.) Tytler P., Calow P., Springer, Dordrecht, 99-124.

Policar, T., Schaefer, F. J., Panana, E., Meyer, S., Teerlinck, S., Toner, D., Żarski, D. (2019). Recent progress in European percid fish culture production technology-tackling bottlenecks. Aquaculture International, 27(5), 1151-1174.

Schulz, C., Knaus, U., Wirth, M., Rennert, B. (2005). Effects of varying dietary fatty acid profile on growth performance, fatty acid, body and tissue composition of juvenile pike perch (Sander lucioperca). Aquaculture Nutrition, 11(6), 403-413.

Sveier, H., Wathne, E., Lied, E. (1999). Growth, feed and nutrient utilisation and gastrointestinal evacuation time in Atlantic salmon (Salmo salar L.): the effect of dietary fish meal particle size and protein concentration. Aquaculture, 180(3-4), 265-282.

Tabachek, J. A. L. (1988). The effect of feed particle size on the growth and feed efficiency of Arctic charr [Salvelinus alpinus (L.)]. Aquaculture, 71(4), 319-330.

Toner, D. (2015). The market for Eurasian perch. In: Biology and culture of percid fishes - principles and practices (Ed.) Kestemont P., Dabrowski K., Summerfelt R. C., Springer, Dordrecht, Netherlands, 865-879.

Wang, J., Pu, H., Tian, X., Zhao, D., Zhong, J. (1994). The role of food particle size in the growth of juvenile carp (Cyprinus carpio L.). Journal of Dalian Fisheries College, 9, 72-77.

Wang, N., Xu, X., Kestemont, P. (2009). Effect of temperature and feeding frequency on growth performances, feed efficiency and body composition of pikeperch juveniles (Sander lucioperca). Aquaculture, 289(1-2), 70-73.

Wanzenböck, J. (1995). Changing handling times during feeding and consequences for prey size selection of $0+$ zooplanktivorous fish. Oecologia, 104(3), 372-378.

Wańkowski, J. W. J., Thorpe, J. E. (1979). The role of food particle size in the growth of juvenile Atlantic salmon (Salmo salar L.). Journal of Fish Biology, 14(4), 351-370.

Zakęś, Z. (2009). Pikeperch. Breeding and rearing. A breeder's guide. Wydawnictwo IRS, Olsztyn, (in Polish).

Zakęś, Z. (1999). The effect of body size and water temperature on the results of intensive rearing of pike-perch, Stizostedion lucioperca (L.) fry under controlled conditions. Archives of Polish Fisheries, 7(1), 187-199.

Zakęś, Z., Hopko, M., Kowalska, A., Partyka, K., \& Stawecki, K. (2013). Impact of feeding pikeperch Sander lucioperca (L.) feeds of different particle size on the results of the initial on-growing phase in recirculation systems. Archives of Polish Fisheries, 21(1), 3-9. 